\title{
AUTHORITARIAN REGIMES IN DEMOCRATIC REGIONAL ORGANISATIONS? \\ EXPLORING REGIONAL DIMENSIONS OF AUTHORITARIANISM IN AN \\ INCREASINGLY DEMOCRATIC WEST AFRICA
}

Dr Edward Stoddard ${ }^{\mathrm{a}}$

Senior Lecturer in International Relations and Contemporary Security

Centre for European and International Studies Research

University of Portsmouth

\section{Author Biography}

Dr Ed Stoddard is a Senior Lecturer in International Relations and Contemporary Security at the University of Portsmouth.

\section{Funding}

This article results from research conducted during a post-doctoral fellowship at the KollegForschergruppe (KFG) 'The Transformative Power of Europe,' hosted at the Freie Universität Berlin. The KFG is funded by the German Research Foundation (DFG).

Key Words: Democracy; Authoritarianism; West Africa; Regionalism; ECOWAS; AU

\footnotetext{
a Contact: Dr Edward Stoddard, ed.stoddard@port.ac.uk
} 


\begin{abstract}
Research suggests regional organisations 'lock in’ their dominant political systems: democratic regionalism stabilises transitioning democracies whilst regionalism in autocratic regions is conversely associated with boosts in authoritarianism. Little research, however, has examined the regional-level trends and tactics that authoritarian leaders have sought to exploit to survive in democratising regions. This article focuses on the West Africa region which has seen considerable democratic progress over the last 20 years. However, while this progress is commendable (demonstrated by the recent transition of formerly autocratic Gambia), the consolidation process is not complete and, as in other parts of the world (such as the EU), democratic backsliding is a present risk. This article explains how authoritarian leaders have sought to use and benefitted from regional dynamics in an otherwise democratising region. It suggests that both formal and informal regional interactions have at times provided benefits that support authoritarianism and suggests a typology of the mechanisms through which this can happen. It serves as a potential guide for other regions in Africa yet to democratise to the level of West Africa, and as a guide to the types of regional authoritarianism-enhancing processes that could be used to support backsliding in (west) Africa and elsewhere.
\end{abstract}

\title{
Introduction
}

Recent literature suggests that regional organisations (ROs) help to support the dominant regime type in a region. ROs with a high level of 'democratic density' provide a climate that boosts democracy (Pevehouse 2002a, 530) whilst, regional cooperation between autocratic states has been shown to boost authoritarian members (Ambrosio 2008; Silitski 2006). Indeed, within the broader research focus on authoritarian states' efforts to resist democratisation and support regime survival, international cooperation, and regionalism in particular, have surfaced as core pillars of authoritarian rule (Kelly 2007; Jackson 2010; Ambrosio 2008; Allison 2008; 
Söderbaum 2010; Yom 2014). In the Middle East and the former Soviet Union, for example, ROs such as the Gulf Cooperation Council (GCC) and the Shanghai Cooperation Organization (SCO) have emerged respectively as means of protecting authoritarian regimes from internal and external democratisation pressures - often supported by an 'illiberal' regional hegemon (such as Russia/China and Saudi Arabia) (Börzel 2015; Kamrava 2012; Libman 2007) and sometimes assisted by so-called 'black knights' from the West that support, or turn a blind eye towards, un-democratic regimes (Ambrosio 2014).

The West African region is, at one level, one of the success stories of global moves towards democracy. Despite some significant challenges, since the 1990s the region has seen considerable increases in democracy levels, supported by both the Economic Community of West African States (ECOWAS) and extra-regional actors such as the EU. However, while ECOWAS has been tasked with promoting democracy since at least the Cotonou Agreement of 1993 (and especially since the in 1999 protocol on Conflict Prevention, Management, Resolution, Peacekeeping and Security and the 2001 protocol on Democracy and Good Governance - see below), the West African region has had a high degree of plurality in terms of democracy/autocracy during the subsequent period and thus overall a relatively low (albeit increasing) 'democratic density' for much of the last two decades. States that underwent earlier democratic transitions in the region, such as Ghana and Cape Verde, have sat for years alongside authoritarian leaders, such as Gambia's recently ousted Yaya Jammeh. A number of West African states today lie somewhere in the middle - 'big man' led, neo-patrimonial, semiauthoritarian hybrid states (Birikorang 2013). This division is reflected very much in representations of the region. West Africa is often presented on the one hand as an area replete with potential and opportunity (Bloomberg Professional 2015). On the other hand, the region is often discussed through representations focusing on poor governance and conflict (IRIN 2014). These latter two are interrelated, with poor governance often having been a root cause 
of violent upheaval (Annan 2014). Both of these representations of West Africa also play into the internal and external constructions of the region and subsequently, the interventions made by external and regional actors. Western fears over China's 'Scramble for Africa', for example, can be seen not just to reflect fears of economic competition, but also of normative competition with the prospect of African states diverging from their democratising paths (Taylor 2011, 130). Similarly, both Western actors and the ECOWAS Commission frame their respective political and military interventions on grounds of establishing or promoting good governance (EEAS 2015; ECOWAS 2015).

This of course raises the question of what role regionalism has played for the more authoritarian members of ECOWAS. Has the regional level represented a wholly hostile environment for them in terms of their hold on power? Or can authoritarian states still derive regime survival benefits from regional level interactions in democratising regions? This article examines the role played by regional dynamics (both regional integration in ECOWAS and the African Union, and formal/informal cooperation in and outside of these bodies) in the support of democracy and autocracy in the West African region. It suggests that while ECOWAS, and the ECOWAS Commission in particular, have a positive record of supporting democratic developments and sanctioning authoritarian backsliding, other regionalist dynamics have been used to support authoritarian states and create space for hybrid systems of un-democratic rule. The contribution of this article is two-fold. Firstly, it proposes a typology of the mechanisms by which regionalism can further the interests of authoritarian states outside of the 'deliberate denial of democracy' forms of authoritarian protection seen in other regions of the world such as Eurasia and the Gulf. Most regional support for authoritarianism in these regions comes about through deliberate actions that aim to bolster autocracy. In the case of West Africa, with a clear overall trend towards democracy, regional benefits for authoritarian leaders do not generally take this form, but rather a series of more subtle mechanisms that reflect the more 
complicated balance between democracy and autocracy and the recent history of the region. These include the subversion of benefits intended (nowadays) for democratic states, difficult trade-offs (especially between stability and democracy), the rejection of Western values seen as political impositions and the ability to derive benefits from multiple fora i.e. ECOWAS and the AU (forum shopping). These mechanisms are then highlighted and examined in the context of West African regionalism, demonstrating how this regionalism has presented politicosecurity and legitimacy-boosting benefits for authoritarian West African leaders.

Beyond the academic contribution, the findings of this article are also relevant in policy terms, both in West Africa and further afield. While the more extreme cases of authoritarianism in West Africa are now largely historic (with the removal of Blaise Compaoré in Burkina Faso in 2014 and Yaya Jammeh in Gambia in 2016, two of the remaining long term autocrats are now gone), it would be nevertheless complacent to assume that the trajectory towards democracy is now complete in the region. Despite the very real progress in terms of democratic transition in West Africa, democracy is not yet consolidated in many West African states. Democratic backsliding is a real danger in West Africa as it is in other parts of the world, including Europe, Latin America and the former Soviet Union (Diamond, Plattner and Walker 2016, 3). The mechanisms and actions described in this article could be used by any future democratic backsliders and may embolden them to launch more egregious attempts to subvert democracy. The information in this article is thus of use to those who would seek to understand both how previous authoritarian leaders sought to use regional cooperation to survive in power and to ensure that others would not be able to do the same in the future. Secondly, there are other regional bodies in Africa such as the Southern African Development Community (SADC) which have experienced democratising trends and have democratising mandates but have mixed memberships in terms of democratic standards and lower overall standards than 
ECOWAS. Knowledge of how authoritarian leaders have sought to use to regional dynamics to support their regimes in ECOWAS is also relevant in this wider African context.

In terms of running order, the article is divided into five sections. The first discusses the role that democracy-promoting regional institutions can have on democracy and contrasts this with the autocratic-boosting effects of other, more authoritarian, regionalisms. The second section assesses the positive role that regional bodies (most notably the ECOWAS Commission) have played in promoting democracy in West Africa, as well as also highlighting the on-going challenges of democratisation in the region. The third section discusses five different mechanisms by which regional cooperation can assist authoritarian states outlining those that are likely to apply in the case of regional cooperation in West Africa. Section four examines how regional cooperation in the West African region has provided politico-security and legitimacy benefits for authoritarian governments. Section five concludes.

\section{Regionalism and the 'Lock-In' of Dominant Regime Types}

Recent Political Science literature suggests that regional organisations (ROs) have the capacity to 'lock in' the dominant political system type within a region (Pevehouse 2002a; Ambrosio 2008; Börzel 2016). Indeed, ROs have played a significant role both in respective waves of democratisation across the globe and the so-called 'backlash against democracy' instigated by a number of authoritarian states since the mid-2000s (Carothers 2006). Regionalism - both in the form of formal regional integration and less formal regional cooperation - appears to play into dynamics of (regional) systemic heteronomy and homogeneity identified by Raymond Aron in the 1960s. He suggested that homogenous systems of states - those with states comprising similar types of government - were likely to be both more stable and that states would thus seek to homogenise (in regime type terms) their environments (Aron 1966, 100). Regional bodies - backed up by regional powers (Hartman 2016; Kamrava 2012; Ambrosio, 
2008) - are one means through which states can collectively encourage more homogenous regional political systems.

\section{Regionalism Boosting Democracy?}

As Pevehouse (2002a; 2002b) has observed, ROs with high 'democratic density' have a propensity to bolster democratic transitions in member states. He suggests a number of factors that contribute to these transitions in member countries, namely; pressure from the ROs themselves to democratise, credible reassurance from other democratic states and socialisation of democratising leaders in democratic norms (Pevehouse 2002a, 519). A wide literature on the European Union (EU), for example, has highlighted the socialisation and conditionality role that the EU has played in the democratisation of its prospective and new member states (Schimmelfennig 2002; 2016). Indeed, the EU's conditionality has been shown to bolster support for democracy and facilitate transition in Eastern European states. Its effect, however, on states once they have joined the EU is less clear (Schimmelfennig 2016, 192; Börzel 2014, 16). Policies of the Fidesz government in Hungary, and more recently of the governing Law and Justice party in Poland, have, for example, raised questions about both governments' commitment to democracy. Overall, however, the EU's record is good with new European member states remaining generally above the level of democracy in non-EU post-communist countries. In Latin America, Ribeiro-Hoffman (2007) has argued that MERCOSUR has used democratic clauses to address democratic deficits and backsliding in member states (notably Paraguay). Similarly, Parish and Peceny (2002) have argued that the Organization of American States (OAS) has utilised its influence to promote the collective defence of democracy in the Americas. At the time of writing, Venezuela has recently been threatened with action by the OAS over its record on democracy (Wilkinson 2017). Taken together, regional organisations characterised by democracy appear to provide an environment conducive to the support of democratisation (notwithstanding some instances of backsliding as mentioned above). 


\section{Regionalism Boosting Autocrats?}

In regions with higher 'autocratic density', regional cooperation has conversely assisted authoritarian states to stay in power. Indeed, 'regime boosting' or 'protective' regionalism is seen as both a tool states can use to manage challenges to their regimes (Allison 2008; Söderbaum 2010; Riggirozzi 2010) and as a core part of the global 'backlash against democracy' (Carothers, 2006).

Perhaps the most marked politico-military examples of this trend was the 2011 Gulf Cooperation Council (GCC) intervention to quell unrest in fellow GCC member state Bahrain (comprising a number of GCC states led by Saudi Arabia) (Kamrava 2012; Ayoob 2011). However, beyond this very visible case, in both the Gulf and the Former Soviet Union (FSU), regional bodies such as the Shanghai Cooperation Organization (SCO), the Commonwealth of Independent States (CIS) and the GCC have also sought to limit domestic political threats by facilitating the sharing of intelligence on dissidents and the extradition of threatening individuals (Toumi 2013; Cooley 2012). In addition, in both regions, regional cooperation has provided a forum for authoritarian learning and policy transfer - facilitating the spread of authoritarian 'political technologies' (Silitski 2010, 342; Yom 2014, 60).

Similarly, in the economic realm one can observe regional cooperation employed to bolster the stability of autocratic regimes. Economic regional bodies such as the Eurasian Economic Union (EEU) in the FSU, and the GCC in the Gulf, offer autocratic states a stronger negotiating position in the world stage. While this does not inherently support autocracy (regionalism does the same for all members of regional bodies whether autocratic or democratic), for autocracies it can present a valuable opportunity to reduce dependence on the West and protect rentgenerating industries that provide the funds of state patronage. Similarly, regional cooperation in the GCC, Eurasia and Latin America facilitates financial transfers from richer to poorer regional partners. Russia has, for its part, heavily subsidised neighbouring EEU-member 
Belarus and remittances from Central Asian migrants working visa-free in Russia play a crucial economic role in CIS countries such as Tajikistan and Kyrgyzstan. The richer GCC states have offered generous financial assistance to Bahrain (and Oman) in the wake of the uprisings there. In Latin America, the regional organization the Alianza Bolivariana para los Pueblos de Nuestra América (ALBA) has, in conjunction with 'PetroCaribe' - a regional mechanism for distributing subsidised Venezuelan oil to other Caribbean and Latin American states facilitated financial flows from a richer member Venezuela to poorer ones, such as Cuba (Piccone and Trinkunas 2014).

Regional bodies can also play a key role in terms of regime legitimacy. Following the 'Colour Revolutions' in the FSU, where flawed elections were trigger points for uprisings, the CIS has sent observers to post-Soviet elections to counter Western monitors who were accused of delegitimising leaders and promoting "regime change" (Silitski 2010, 348; Fawn 2006, 1144; Cooley 2012, 110). This has been followed by the SCO who, since 2005, has also sent monitors to post-Soviet elections (Boland 2011, 16; Cooley 2012, 114). The outcomes of these election missions have always been favourable for incumbent governments - regardless of their democratic character. Elsewhere in the Gulf, the GCC has consistently promoted traditional cultures as sources of legitimacy (Islam, tribal culture and monarchy) (Haimerl 2013, 10; Albrecht and Schlumberger 2004; Colombo 2012, 10). Finally, as Söderbaum (2010) has noted, well-publicised regional summits and informal cooperation between leaders provides a means by which state leaders can mutually support each other's legitimation and bolster each other's public image.

\section{Regionalism, ECOWAS and Democratisation in West Africa}

While its impact has been limited in a number of ways (discussed below), ECOWAS (the principal regional body in West Africa) has sought - in many cases successfully - to 'lock in' 
and support democracy in the West Africa region, especially following a number of governance and security crises. ECOWAS was established in 1975 with an economic rather than democracy/good governance, or peace and security mandate (Yabi 2010, 10). While none of its members were democratic at its inception (Hartmann, 2013, 8), this changed after the Cold War as ECOWAS began to develop a good governance agenda following the devastating security conditions of the 1990s where military conflicts (especially Liberia, Sierra Leone, Guinea) and repeated military coups undermined the political and economic development of the region. These crises were thought to have their roots in poor governance, maladministration and corruption, the absence of effective accountability, ethnic marginalization and limited checks on power (Annan 2014, 3). Reflecting this, ECOWAS bolstered its democratic mandate and was the first RO on the African continent to institutionalise an agenda on democracy and good governance (Hartmann, 2013, 7). However, this means of course that, unlike the EU for example, ECOWAS did not have good governance and democracy standards as a criterion of membership and thus both the regional organisation itself, and the states within it, have democratised in tandem.

In 1991, ECOWAS states issued a 'Declaration of Political Principles' that expressed the desire 'to promote democracy in the sub-region on the basis of political pluralism and respect for fundamental human rights' (ECOWAS 1991). These principles were reaffirmed with the signing of the Cotonou Treaty - the Revised ECOWAS Treaty - in 1993 (Hartmann 2013, 11). However, the major institutional changes in terms of democracy and good governance came at the end of the 1990s. The 1999 'Protocol Relating to the Mechanism for Conflict Prevention, Management, Resolution, Peace-Keeping and Security' strengthened ECOWAS commitment to democracy (albeit still quite vaguely) and, crucially, established a mechanism by which states could intervene in the event of massive humans rights abuse or an unconstitutional change of government (based on the decision of nine out of the fifteen states in the ECOWAS 
'Mediation and Security Council') (Hartman 2013, 18). In doing so, it instigated a strong means of intervening in crises on the side of human rights and democracy. The most explicit definition of ECOWAS' role in the promotion of good governance, however, came in the 2001 'Supplementary Protocol on Democracy and Good Governance' (Yabi 2010, 12). This document outlines much more specifically the democratic features that ECOWAS states should possess (including, inter alia, stipulations on elections, separation of powers, changes to constitutions, the apolitical role of the military etc.) and agrees a set of convergence criteria that states should aim to meet (Hartmann 2013, 19).

However, while these initiatives significantly advanced the democratic character of ECOWAS and its crisis reaction mechanisms, the 1999 Protocol and 2001 Supplementary Protocol are much weaker, by contrast, on measures to promote good governance in normal times (i.e. in the absence of major upheaval) (Hartman 2013, 18). Indeed, due to the limited scope for the active promotion of democracy in member states, ECOWAS (in particular the ECOWAS Commission) has only made notable efforts towards the protection of democracy, in practice, in the wake of political and security crises where the Commission is empowered to act (Hartmann 2013, 35; Bappah 2014, 96). A number of recent examples include responses to unconstitutional changes of government (UCG). In several cases of UCG, such as coups and attempts to illegally extend presidential term limits (c.f. Niger, Mali, Guinea, Burkina Faso, Gambia amongst others) ECOWAS has sanctioned rule-violators and insisted on return to democratic governance. ECOWAS has then overseen transitions and monitored subsequent elections. Outside of these crisis periods, however, the ECOWAS Commission has been limited in its capacity for action and ECOWAS states (many of whom with less than perfect democratic records) have been, perhaps unsurprisingly, reluctant to encourage democracy regionally. Indeed, overall ECOWAS's record on democracy is thus mixed in its effects. Despite the activism of the Commission and the support for democratic change in response to crises, 
outside of major upheavals the body as a whole is dependent for democracy support on the ECOWAS heads of state (who have often been not keen to promote democracy) and the mechanisms for actively promoting democracy before crises emerge (while envisaged in the protocols) are weak and largely uninitiated (Bappah 2014, 97).

\section{Regional Support for Authoritarian Leaders: Mechanisms}

While many instances of 'protective' or regime-boosting regionalism examined in the literature (Allison 2008; Söderbaum 2010) reflect a conscious regional effort to subvert democracy, this is unlikely today in the West Africa region (especially from ECOWAS) given the clear mandate for democracy promotion that has evolved over the last two decades. Here we are talking of a democratising region with an RO possessing an explicit mandate to promote democracy. It is nevertheless a region with a concurrent coexistence between more authoritarian and more democratic regimes and, as the section below will argue, numerous means through which authoritarian leaders have been able to derive benefits from regional dynamics. This makes it quite different from for example the overwhelmingly democratic EU or the overwhelmingly autocratic SCO or GCC where the support for regime type is explicit (in the EU case) or at least entirely deliberate and evident in its autocratic effects (in the latter two cases for example). The picture in West Africa is much more nuanced, born of the far less determinate balance between regime types, the fact that all ECOWAS states were (largely authoritarian) members before ECOWAS was mandated to promote democracy and the challenging, albeit generally positive, moves towards democracy in the region.

This section outlines five different mechanisms by which regional cooperation can provide regime-support benefits for authoritarian leaders. It is crucial to make a distinction between these mechanisms to fully understand how ostensibly democratic regional organization, such 
as ECOWAS, may have come to offer space for authoritarian leaders. The five mechanisms are as follows:

1) Deliberate autocratic benefits/denial of democracy. Firstly, as described above, in contrast to their stated objectives and reflecting the will of some member states, a regional body might offer deliberate support to authoritarian states in an effort to quell the risk of democratic transition, as other regional bodies such as the GCC and SCO have done in the face of protests and uprisings. This seems an unlikely mechanism to expect in the case of regional cooperation in West Africa.

2) (Formal) Benefits of regionalism are subverted. It could also be the case, however, that regional bodies provide benefits for their members as a whole that bolster democracies and autocracies equally, or that measures designed to promote democracy or other public goods can be (ab)used by authoritarian regimes to their own advantage. Söderbaum (2004) has talked of 'sovereignty boosting' regionalism in Africa for example. Such effects are likely to enhance the capacity of weak states regardless of regime type.

3) Difficult trade-offs can benefit authoritarian leaders. It might also be the case that regional bodies and external powers are faced with unenviable trade-offs that might work to the advantage of authoritarian leaders, the most fundamental and common being trade-offs between security and human rights, and similarly, stability and democracy. Equally possible in some cases is a trade-off between democracy and development. Here ROs may take an action that boosts an authoritarian leader, but only because the alternative (insecurity/instability/weak development) is seen to be worse.

4) Rejection of Western norms. Regionalism can offer authoritarian leaders the capacity to boost their image through the rejection of Western norms that are claimed to be cultural or 
political 'neo-colonial' impositions that work to the disadvantage of African leaders. This can function in two senses. On the one hand regionalism can offer a collective rejection of external values that are seen as being imposed by external actors. On other hand. It is also possible that regional bodies may be used for regime-boosting purposes by authoritarian states against the wishes or interests of the RO. Unpopular regional policies that are seen to be Western in origin, for example, may be rejected by authoritarian states for their own benefits. Alternatively, authoritarian leaders may blame ROs for difficult problems and avoid having to deal with them domestically. This benefit is common in democratic ROs such as the EU where member state leaders can either blame the EU for unpopular things they would actually like to do or whether they can define themselves against the EU values to boost legitimacy and support amongst certain demographics that are critical of the EU.

5) Overlapping regionalism/regional 'forum shopping': Finally, while one regional body may advance a more democratic agenda, it is possible that authoritarian states or their regional/extra regional supporters may, in a given instance, use or advocate the policies of another overlapping regional body with less reliable democratic credentials. The role of the African Union in this regard will be touched on below. Equally possible is the utilisation of alternative forums (including informal ones - see below).

\section{Regional Dynamics and Authoritarianism in West Africa}

Having discussed the mechanisms by which regionalism may support autocracy in West Africa, it is now necessary to examine how these have manifested in practice. This section discusses a number of the means by which authoritarian leaders in West Africa have been aided by regional cooperation to defend themselves against internal and external threats. The different mechanisms described above (subverted, trade-offs, norm rejection and forum-shopping) by 
which regionalism can be used to support authoritarianism, both within ECOWAS and the AU, will be highlighted and discussed.

\section{Subverted Politico-Security Benefits}

In the politico-security realm, regional cooperation in West Africa offers two subverted benefits in particular for authoritarian leaders: regional coup deterrence and positions of regional security importance. The first - regional deterrence of coups - assists with what is historically the primary domestic threat to autocrats globally (see, Kendall-Taylor and Frantz, 2014). ECOWAS and the African Union have developed strong protocols to respond to 'unconstitutional changes of government' (UCG), especially coups d'état (Witt 2013, 259; Omorogbe 2011). In 2000, the (then) Organisation for African Unity (OAU) outlined a number of conditions that would constitute UCG, namely; military coups, intervention by mercenaries, replacement of government by armed dissidents and refusing to step down having lost an election (Witt 2013, 259). The 2007 AU African Charter on Democracy, Elections and Governance (in force since 2012) widened the focus to include unlawful constitutional changes and barred coup-participants from taking part in post-coup elections. The ECOWAS Protocol on Democracy and Good Governance (2001) presents similar provisions, but goes further, permitting possible military action in the event of UCG.

However, the history of anti-coup actions at a regional level in Africa predates widespread democratisation in the continent and the original motivations for seeking to avoid coups under the Organisation for African Unity (the precursor to the African Union) were order and stability preservation rather than democracy preservation. States (of all types) in the region feared that they might themselves also be removed in a coup (perhaps backed by foreign powers) and wished to deter this from happening (Cowell 2011, 335). As Cowell $(2011,335)$ notes, while the 1990/2000s saw a growth in the democratisation agenda and adoption protocols outlining 
commitments to democracy within African regional organisations, in practice, the application of these protocols 'has focused almost exclusively on the threat of unconstitutional changes of government and not on enforcing norms promoting good governance'. Indeed, rules against unconstitutional changes of government work to the benefit of incumbent states (including authoritarian ones) as a lack of prior domestic democratic governance does not stop the AU and other regional bodies condemning, excluding and sanctioning coup leaders (Omorogbe 2011). This includes cases where their coups potentially may have made a path toward democracy more likely or when militaries had originally intervened to stop unconstitutional behaviour (Omorogbe 2011). These provisions represent an example of 'subverted benefits' in that, while coup provisions do have the effect of protecting democratic orders and help to punish coup leaders after a coup (which is today their stated purpose in ECOWAS), in practice they function to deter coups in both democratic and autocratic states alike. Similarly, this benefit also derives from trade-offs between the stability afforded by an entrenched regime and the risks associated with unpredictable and often deleterious domestic upheaval.

Beyond coups however, regional cooperation can also aid authoritarian leaders by increasing their importance as security actors and, in turn, their leverage vis-à-vis Western actors who are in turn less likely to push democratisation. Autocratic leaders have also used (and tried to use) ECOWAS as a means of boosting their regional security importance through regional conflict mediation. Blaise Compaoré, former (authoritarian) president of Burkina Faso was valued as a 'regional leader' by France and some West African states for his role as a conflict 'mediateur'. Indeed, he was appointed by ECOWAS as a mediator in the Mali crisis (Panapress 2012). These mediation roles, according to one commentator, 'bolstered the president's credentials as a peacemaker - and largely exonerated him from Western criticism over his dubious democratic record' (Dodman 2014). Indeed, Compaoré was thought to be 'un ami fidèle de la France' and pillar of Paris's 'francafrique' policy, in addition to being a US ally in the region (Jaffré 2010). 
Such opportunities (while possibly prudent from a security point of view) demonstrate external actors' trade offs and the subversion of official regional posts that can be used to boost the prestige of leaders and may make them more likely to receive support from 'black Knight' Western powers (and consequently thus less likely to be 'dropped' by them when they face political challenges). The particular case of Compaore is all the more problematic for the destabilising role he is thought to have played in numerous West African conflicts (Campbell 2014). Similarly, Wikileaks cables reveal that Gambian president Jammeh sought to boost his international recognition by being seen as a regional security broker and negotiator - although such efforts were less successful than Compaoré in his case (US State Department 2001)

\section{Trade-offs and 'forum shopping' around elections}

Regionalism can aid authoritarian leaders with another important element of regime survival legitimation around flawed elections - and this presents often difficult trade-offs for regional bodies and opportunities for forum shopping. Many of the states in West Africa either have been or currently are 'competitive authoritarian' or 'hybrid' orders: states where political power is ostensibly achieved through winning elections, but where elections are controlled in such a way as to make victory for the incumbents highly likely. Under such circumstances, elections serve a fundamental role of legitimating an authoritarian leader's tenure on power (rather than being a genuine means for leadership change) (D'anieri 2014, 80). Regional bodies (such as ECOWAS and the AU) play an important part in elections given their election monitoring roles. ECOWAS and the AU (the latter in particular), have both come under criticism for sanctioning flawed elections with their results, at times, diverging from international observers. Both the AU and ECOWAS conduct relatively short electionmonitoring missions that focus more on the technical administration of elections rather than the broader electoral process (that often lasts many weeks). ECOWAS is considered to adopt a 
'developmental' rather than 'judgemental' approach to election monitoring, seeking to 'improve, rather than ostracise' (Mediation Support Network, 2013). Indeed, while ECOWAS's democratic standards are more substantive than the AU overall, it has faced criticism over its election monitoring. Examples include the monitoring of elections in Togo in 2005 where ECOWAS (along with the AU) is thought to have given (despite serious irregularities) broadly positive assessments to the election of Faure Gnassingbé (Bittiger, n.d.). Part of the challenge in the Togo case was ECOWAS's joint mandate (with attendant tradeoffs) as both mediator and then subsequent validator of elections (Bittiger, n.d.). ECOWAS was tasked with both finding a solution of the crisis, and evaluating the elections that were part of that same process. Bittiger (n.d.) suggests that they were then accused of 'white-washing' the result in effort to promote stability in Togo. Some thus fear that joint stability/election monitoring mandates may create trade-off incentives for ECOWAS to approve less-thanperfect election processes.

ECOWAS has in the past refused to monitor some elections over democracy and human rights concerns. Gambian presidential elections in 2011 were boycotted by ECOWAS because the country did not have, according to ECOWAS, a political environment conducive to holding free and fair elections (BBC 2011). The African Union, by contrast, and representing in this case an alternative forum, did send observers in 2011 and found the results to be credible and the conduct of the elections impressive (Clottey 2011). Their results were indeed quite divergent from the opinion of ECOWAS, with the head of the AU mission arguing they 'give them [the Gambian government] a good pass mark. On the whole, they did more than well' (Clottey 2011). Election monitoring provides a crucial mark of legitimacy on elections especially important in competitive authoritarian regimes.

\section{Rejection of Western values}


Regional cooperation can help to challenge Western authority and the universalism of Westernderived international norms. A recent example has been AU efforts to reduce the influence of the International Criminal Court (ICC) in Africa. The majority of ICC prosecutions have been against African individuals, including a number of state leaders including President Bashir of Sudan and President Kenyatta of Kenya (du Plessis, Maluwa and O'Reilly 2013). The disproportionate number of African prosecutions has led to suggestions of 'neo-colonial' bias in ICC cases and has been strongly resisted by the AU. The actions of the court have been thought by some to violate the 'sovereignty and territorial integrity of the concerned countries' (Jalloh 2010, 2). Some have suggested that the rejection of ICC in Africa (which is not universally rejected by African governments) is driven by autocratic leaders who are concerned that they themselves may one day 'need to' take action that would contravene the courts principles (The Economist 2011). Prosecutions (both actual and attempted) have been linked to post-election violence. Laurent Gbagbo, former president of Cote d'Ivoire, is currently before the ICC charged with instigating post-election violence in 2010/11 and the ICC was for a time seeking to try Uhuru Kenyatta, the serving President of Kenya, over accusations of instigation of election violence in 2007/8. However, while ICC denunciation may be selfserving in some cases for particular leaders, the wider rejection of the ICC also demonstrates a number of the founding values of the AU that hold traction across Africa; in particular, panAfrican solidarity, the reinforcement of an 'African' way of doing things and rejection of universality of values (and jurisdictions), the re-enforcement of state sovereignty (a guarantor of the latter) and the rejection of perceived neo-colonialism. However, legitimate promotion of international pluralism can open the way for authoritarian leaders to reject pluralism at a domestic level. In such cases, the assertion of sovereignty, while the right of all states, can be subverted and may work to the advantage of authoritarian leaders. 
An interview with former Gambian President Yahya Jammeh on the eve of Gambia's recent celebrations of 50 years of independence exemplifies the way in which pro-sovereignty, anti neo-colonialist arguments can be used for authoritarian legitimation by linking democratic states in West Africa to neo-colonial powers. Jammeh suggests that all Gambians should ask themselves 'what is democracy' and then answers his question by stating that: 'it is not the 'derimocracy' [sic] where I am here, but representing foreign interest, and I allow them to rob my country of her resources and later you call me one of the leaders of Africa and paste me on their mass media'. He suggests that a number of ECOWAS states are led by and funded by 'Western powers' and argues that this is negative trend that affects both ECOWAS and the AU (Jammeh 2015). ECOWAS, according Jammeh (2015) works against 'independent African leaders who have a sense of dignity and pride [and] who want Africa to be something better than what we are today' (with the implication being that he is one of these independent leaders). Here Jammeh sets himself in partial opposition to ECOWAS, and employs a de-legitimation of ECOWAS as a means of self-legitimation (in a strategy that is not dissimilar to some British Governments' approaches to the EU). Reflecting his anti (neo) colonialist legitimation strategy, Jammeh presents himself as opposed to some ECOWAS decisions that he argues are neocolonial impositions, noting, 'when you look at most of the ECOWAS decisions that we always object to are decisions that did not come from us but that came from outside - the West, the same thing they are trying to do with AU' (Jammeh 2015).

Overall, the West African/ECOWAS position on resisting the West is less strident than that of the AU as a whole. But this middle ground, however, puts ECOWAS in an unenviable position. If it moves to far to promote 'Western' values it can face criticism on grounds of its independence with the more authoritarian elements in West Africa de-legitimising the organization for their own purposes. Moving against 'Western values' would bring pressure 
from the West and go against ECOWAS's stated objectives, despite the fact that it might be positive in terms of domestic legitimacy (and may well be justified at times).

\section{Subversion of regional fora and positions for regime boosting}

Regional fora and formal positons has also been used to boost the 'big man' image of authoritarian state leaders and promote their regimes. Authoritarian rule in many states rests on various forms of charismatic legitimacy where the legitimacy of the state as a whole is associated with the legitimacy of its leader (Osaghae 2010, 408-9; Söderbaum 2010, 5). Such images, however, require cultivation and benefit from international recognition. A core feature of regionalism that facilitates this image-boosting is 'summitry' - high profile and formal meetings that receive much attention where leaders can demonstrate the importance and prominence of their regimes and support each other through joint legitimation (Söderbaum 2010, 7). Informal gatherings of regional leaders can potentially have similar effects as well. For example, despite Gambia's poor democracy and human rights record, the $50^{\text {th }}$ anniversary celebrations of Gambian independence in 2015 were attended by a range of regional foreign dignitaries including President Mahama of Ghana (then chairman of ECOWAS), President Vaz of Guinea Bissau, President Ould Abdel Aziz of Mauritania, Vice President Sambo of Nigeria and Senegalese Vice President Dionne (Amin 2015). While the event was not a formal meeting in ECOWAS or the AU, this form of visible public support from regional leaders lends a degree of legitimacy to Jammeh and boosted his public image (also interesting given that ECOWAS as a whole boycotted the Gambian elections in 2011 as noted above). Drawing attention to this support, Jammeh publically noted his appreciation for their having attended the celebrations in his Independence Day speech (Amin 2015). Such actions appear to fit within a specific regional strategy employed by the Gambian leader. Indeed, Jammeh's West African strategy was reportedly driven more by a personal desire to be seen as a regional diplomacy broker and 
charismatic regional leader, than by efforts to achieve substantive policy goals (US State Department 2001).

In the same vein, ROs offer positions of responsibility that can be used to boost the status of leaders. Both ECOWAS and the AU, for example, have rotating position of Chairperson. This is a prestigious position, which affords the holder a number of important benefits including high levels of regional and domestic visibility, support from other leaders and a key role in regional developments. These positions, somewhat like summits, afford leaders with opportunities and resources to present themselves to their citizenries as important, statesmanlike and key to the regional politics of West Africa - key sources of legitimation and image boosting. A good number of the individuals who have been ECOWAS chairperson have been leaders of democratically elected governments (especially recently), but other authoritarian leaders such as Blaise Compaoré (Chairman 2007-08), and others such as former Nigerian President Umaru Musa Yar'Adua (Chairman 2008-2010) who was elected under widely criticised elections (BBC, 2007) have occupied the position. Indeed, a high level of democracy is not a precondition for being voted into this role and the rotating nature of the position and the fact that authoritarian or weakly democratic leaders can fulfil this role provides an additional regional benefit in terms of legitimation. Such a situation is less of a risk presently in West Africa given the successful transition of most states (and the recent transitions of some of the most autocratic i.e. Gambia), but it should not be discounted considering the precarious position of democracy in some West African states. This is however a bigger issue in the AU where the make-up of member states is far less democratic overall and where several authoritarian leaders, including former Libyan President Muammar Gadhafi (2009-10) and President of Zimbabwe Robert Mugabe (2015-16), have held the position of Chairperson in recent years. 


\section{Conclusion}

In a number of regions across the globe, different regionalisms have played a crucial role in influencing both the spread of, and resistance to, democracy. The West African region is no exception, with the region as a whole, and ECOWAS in particular, having a positive record when it comes to democratic transition. When focusing on the link between democracy/autocracy and regime type, the region presents a particularly interesting example given the regime type heterogeneity in West Africa over the last two decades since ECOWAS started its transition to democracy. In most cases regions with a high 'democratic density' have encouraged democracy, and regions with high levels of authoritarianism have developed to offer a defence against democratisation. The level of democratisation in West Africa, however, has been mixed but growing over the last few decades, and this therefore raises the question of how authoritarian and hybrid states seek to survive in a region that is increasingly committed to democracy.

As this article has shown, regional cooperation in West Africa and engagement in the wider AU, despite the increasingly democratic outlook and mandate of ECOWAS and the AU, has at times offered political and legitimacy benefits to the more authoritarian leaders in the region. This article offered a typology of the different mechanisms through which regionalism in West Africa aids authoritarian and hybrid states to understand the means by which this happens. In West Africa, we do not really see a deliberate regional denial of democracy (as seen in other instances of regional cooperation such as the Gulf), but rather we a see a number of different mechanisms that operate more. They are: A) that less democratic leaders have been able to take advantage of provisions designed in most cases for other (more democratic) purposes and use them to their advantage; B) that difficult trade-offs exist between security and democracy, and that these sometimes work to the advantage of authoritarianism; C) that leaders can counterintuitively use contentious especially Western-derived policies or actions at a regional level to 
legitimise themselves; and D) that overlapping memberships in multiple regional blocs (in this case ECOWAS and the AU) can sometimes offer advantages for authoritarian leaders. Building on these mechanisms, this article has drawn empirical attention to a number of the political and legitimacy-boosting benefits more authoritarian leaders have been able to derive from West African regionalism. In an example of subverted benefits, formal positions of influence, such as the ECOWAS Chairmanship and informal regional security roles, have been used by authoritarian /hybrid leaders to create the space needed for undemocratic practices. Similarly, coup provisions, for example, cannot be denied to authoritarian leaders because coups are insecurity inducing and undemocratic. In addition, other states in the region, regional level authorities (ECOWAS) and external actors have had to make very difficult trade-offs in West Africa such as those between democracy and stability - especially around elections. Similarly, leaders with the capacity to contribute to regional security (such as Compaore and, albeit outside of ECOWAS, Idriss Deby in Chad) have been able to use their security roles to deflect attention from their less-than-democratic regimes. Many of the regional functions described above are designed for weak and developing states or apply in a region characterised by state fragility and the regional functions to address these weaknesses can in some cases be used to bolster both regime types - democratic or authoritarian. Leaders such as Jammeh in Gambia, have much like leaders in some European countries, used rejection of the policies and actions of ECOWAS to legitimise themselves. Similarly, rejection of the ICC at the AU level provides a similar function. Finally, evidence discussed above shows also how overlapping regionalism, especially regarding the AU (which has a less democratic membership overall), also has the potential to provide leaders with certain forms of benefit.

The fact that these 'loopholes' of democratic regionalism exist is in part a legacy of the fact both that ECOWAS and the AU had no initial democratic standards in terms of membership at their outset, have limited means for promoting democracy outside of major crises (such as 
unconstitutional changes of government or unconstitutional efforts to extent term limits) and are tasked with providing benefits for all their members regardless of regime type. Authoritarian leaderships have been able to survive (for a time at least) alongside other democratising states, in part, by exploiting these gaps.

Despite, the growth of democracy in West Africa, pockets of weak governance persist and backsliding towards authoritarian practices remain possible. Whilst the democratic record of ECOWAS as an institution inspires confidence (especially in response to crises c.f. the recent crisis in Gambia), regional cooperation appears to have, at times, presented support for both democracy and opportunities for authoritarian leaders simultaneously. The information presented here should thus be of interest to those both that would seek to insulate West Africa against any autocratic resurgence (as seen elsewhere: Diamond, Plattner and Walker [2016]; Freedom House [2017]) and those that would seek to encourage democracy in other parts of the African continent (and perhaps elsewhere too). While it is by no means easy, reducing the potentially mixed effects of regionalism for governance in Africa will support the growing democratic identity in the region with attendant benefits for security and development in the long term.

\section{References}

Albrecht, H. and Schlumberger, O. 2004. “"Waiting for Godot”: Regime Change without Democratization in the Middle East”, International Political Science Review 25 (4): 371392.

Allison, R. 2008. "Virtual Regionalism, Regional Structures and Regime Security in Central Asia”, Central Asian Survey 27(2): 185-202. 
Ambrosio, T. 2008. "Catching the 'Shanghai Spirit': How the Shanghai Cooperation Organization Promotes Authoritarian Norms in Central Asia", Europe-Asia Studies 60 (8): $1321-1344$

Ambrosio, T. 2014. "Democratic States and Authoritarian Firewalls: America as a Black Knight in the Uprising in Bahrain”. Contemporary Politics 20 (3): 331-346.

Amin, A. 2015. "Gambia Celebrates 50th Independence Anniversary in Grand Style." All Africa. Accessed 20 ${ }^{\text {th }}$ March 2017. http://allafrica.com/stories/201502201319.html

Annan, N. 2014. "Violent Conflict and Civil Strife in West Africa". Journal of Security and Development 3 (1): 1-16

Aron, R. 1966. Peace and War. London: Weidenfeld \& Nicolson Ayoob, M. 2011. “The GCC Shows its True Colours." Foreign Policy. Last accessed $5^{\text {th }}$ April 2017: http://foreignpolicy.com/2011/03/16/the-gcc-shows-its-true-colors/

Bappah, H. 2014. ECOWAS and the Promotion of Democratic Governance in West Africa. Journal of International Relations and Foreign Policy, 2(1), 85-102.

BBC News 2007. "Huge Win for Nigeria's Yar'Adua.” BBC, last accessed $9^{\text {th }}$ April 2017: http://news.bbc.co.uk/1/hi/world/africa/6584393.stm

BBC News 2011. “Gambia's Yahya Jammeh ready for 'billion-year' rule.” BBC, last accessed $11^{\text {th }}$ April 2017 http://www.bbc.co.uk/news/world-africa-16148458

Birikorang, E. 2013 "Lessons Learned and Best Practice from a Troubled Region: ECOWAS and the Development of the ECOWAS Standby Force." Towards an African Peace and Security Regime: Continental Embeddedness, Transnational Linkages, Strategic Relevance. England: Ashgate.

Bittiger, T. (n.d). "Election Observation in West Africa: The ECOWAS Experience.” ACE Project, last accessed $9^{\text {th }}$ March 2015: https://aceproject.org/today/feature-articles/electionobservation-in-west-africa-the-ecowas-experience 
Bloomberg Professional 2015. “Opportunities in West Africa’s Capital Markets.” Bloomberg, last accessed September $28^{\text {th }} 2016$ :

http://www.bloomberg.com/professional/blog/opportunities-in-west-africas-capital-markets/ Börzel, T. 2014. Coming Together or Drifting Apart? MAXCAP Working Paper Series No. 3.

Börzel, T. 2015. "The Noble West and the Dirty Rest? Western democracy promoters and illiberal regional powers". Democratization 22(3): 519-535.

Börzel, T. 2016. Theorizing Regionalism: Cooperation, Integration, and Governance. In T Börzel \& T Risse (Eds.), The Oxford Handbook of Comparative Regionalism (41-63). Oxford: Oxford University Press.

Campbell, J. 2014. Burkina Faso's Compaore and Surrogate Wars. Council on Foreign Relations last accessed 20 $0^{\text {th }}$ January 2015: http://blogs.cfr.org/campbell/2014/11/04/burkinafasos-compaore-and-surrogate-wars/

Carothers, T. 2006. “The Backlash against Democracy Promotion.” Foreign Affairs (85) 2: 5568.

Clottey, P. 2011. “African Union Observers Impressed With Gambia Election.” VOA last accessed $23^{\text {rd }}$ February 2015: http://www.voanews.com/content/african-union-observersimpressed-with-gambia-election--134467893/159238.html

Colombo, S. 2012. The GCC countries and the Arab Spring. Between outreach, patronage and repression. IAI Working Papers 12:09 last accessed 23 ${ }^{\text {rd }}$ January 2015: http://www.iai.it/sites/default/files/iaiwp1209.pdf

Cooley, A. 2012. Great Games, Local Rules: The New Great Power Contest in Central Asia. Oxford: Oxford University Press.

Cowell, F. 2011. "The Impact of the ECOWAS Protocol on Good Governance and Democracy." African Journal of International and Comparative Law 19(2). 
D'anieri, 2014. "Autocratic Diffusion and the Pluralization of Democracy" in Power in a Complex Global System. Edited by Jentleson, B. and Pauly, L. London: Routledge.

Diamond, L., Plattner, M. F., \& Walker, C. (Eds.). 2016. Authoritarianism goes Global: The Challenge to Democracy. JHU Press.

Dodman, B. 2014. The African Peacemaker Who Faced Rebellion at Home. France24 last accessed $24^{\text {th }}$ February 2015: http://www.france24.com/en/20141030-blaise-compaoreafrican-peacemaker-burkina-faso-charles-taylor

Du Plessis, M., Maluwa, T., and O’Reilly, A. 2013. “Africa and the International Criminal Court." Chatham House last accessed $23^{\text {rd }}$ February 2015: http://www.chathamhouse.org/sites/files/chathamhouse/public/Research/International\%20La w/0713pp_iccafrica.pdf

EEAS. 2015. "EU Relations with Mali.” EEAS last accessed $10^{\text {th }}$ September 2015: http://eeas.europa.eu/mali/index_en.htm ECOWAS. 1991. "Declaration of Political Principles.” EODS last accessed $11^{\text {th }}$ April 2017: http://www.eods.eu/library/ECOWAS_Declaration\%20of\%20Political\%20Principles\%20of\% 20the\%20Economic\%20Community\%20of\%20West\%20African\%20States_1991_EN.pdf ECOWAS. 2015. "Political Affairs.” ECOWAS last accessed $10^{\text {th }}$ September 2015: http://www.ecowas.int/ecowas-sectors/political-affairs/ Fawn, R. 2006. "Battle over the Box: International Election Observation Missions, Political Competition and Retrenchment in the Post-Soviet Space." International Affairs 82 (6) 1133 1153.

Freedom House. 2017. "Freedom in the World 2017." Freedom House last accessed $9^{\text {th }}$ April 2017: https://freedomhouse.org/sites/default/files/FH_FIW_2017_Report_Final.pdf 
Fombad, C. M. 2006. "The African Union, Democracy and Good Governance," in $A U$, NEPAD and the APRM: Democratisation Efforts Explored. Edited by Melber, H. Uppsala: Nordic Africa Institute.

Haimerl, M. 2013. In Search of Legitimacy in Times of Crisis. Governance Transfer by the Gulf Cooperation Council (GCC). Berlin Working Paper on European Integration 18.

Hartmann, C. 2013. Governance Transfer by the Economic Community of West African States (ECOWAS). SFB 700 Governance in Areas of Limited Statehood Working Paper 47. Hartmann, C. 2016. "Leverage and Linkage: How Regionalism Shapes Regime Dynamics in Africa." Zeitschrift für Vergleichende Politikwissenschaft 10: 79-98.

IRIN. 2014. "Understanding the Root Causes of Violent Extremism in West Africa." IRIN, last accessed $23^{\text {rd }}$ September 2015: http://www.irinnews.org/report/98012/understanding-thecauses-of-violent-extremism-in-west-africa

Jackson, N. 2010. "The Role of External Factors in advancing Non-Liberal Democratic Forms of Political Rule: a Case Study of Russia's Influence on Central Asian Regimes." Contemporary Politics 16 (1): 101-118.

Jaffré, B . 2010. Le Burkina Faso, pilier de la « Françafrique ». Le Monde Diplomatique last accessed $24^{\text {th }}$ August 2015: https://www.monde-diplomatique.fr/2010/01/JAFFRE/18714 Jalloh, C. 2010. “Universal Jurisdiction, Universal Prescription? A Preliminary Assessment of the African Union Perspective on Universal Jurisdiction." Civil Law Forum. 21(1): 1-65. Jammeh, Y. 2015. “Jammeh Exclusive.” The Gambian Daily Observer last accessed $3^{\text {rd }}$ March 2015: http://wp.observer.gm/jammeh-exclusive/

Kamrava, M. 2012. “The Arab Spring and the Saudi-Led Counterrevolution.” Orbis, 56(1): 96104.

Kelly, R. 2007. "Security Theory in the 'New Regionalism."” International Studies Review 9(2): 197-229. 
Kendall-Taylor, A., and Frantz, E. 2014. "How Autocracies Fall.” The Washington Quarterly, 37(1): 35-47.

Libman, A. 2007. "Regionalisation and Regionalism in the Post-Soviet Space: Current Status and Implications for Institutional Development.” Europe-Asia Studies 59(3): 401-430.

Mediation Support Network. 2013. "Regional Intergovernmental Organizations in Mediation Efforts: Lessons from West Africa." Mediation Support Network last accessed $3^{\text {rd }}$ February 2015: http://mediationsupportnetwork.net/wp-content/uploads/2013/06/Discussion-Points3_Regional-Intergovernmental-Organizations-in-Mediation-Efforts_WEB.pdf

Osaghae, E. 2010. "The Limits of Charismatic Authority and the Challenges of Leadership in Nigeria." Journal of Contemporary African Studies, 28(4): 407-422.

Omorogbe, E. 2011. "A Club of Incumbents? The African Union and Coups d'État." Vanderbilt Journal of Transnational Law 44: 123-154.

Panapress. 2012. ECOWAS names President Compaore as Mediator in Mali Rebellion. Panapress last accessed $3^{\text {rd }}$ June 2015: http://www.panapress.com/ECOWAS-namesPresident-Compaore-as-Mediator-in-Mali-rebellion---12-823841-100-lang2-index.html Parish, R. and Peceny, M. 2002. "Kantian Liberalism and the Collective Defense of Democracy in Latin America." Journal of Peace Research 39 (2): 229-250

Pevehouse, J. 2002a. "Democracy from the Outside-In? International Organizations and Democratization.” International Organization 56 (3): 515-549.

Pevehouse, J. 2002b "With a Little Help from My Friends? Regional Organizations and the Consolidation of Democracy." American Journal of Political Science, 46 (3): 611-626.

Piccone, T. and Trinkunas, H. 2014. "The Cuba-Venezuela Alliance: The Beginning of the End?" The Brookings Institution 2.2: 1-12.

Ribeiro-Hoffmann, A. 2007. "Political Conditionality and Democratic Clauses in the EU and Mercosur". In Closing or Widening the Gap: Legitimacy and Democracy in Regional 
Integration Organisations, edited by Andrea Ribeiro Hoffman and Anna van der Vleuten, 173-192. Ashgate: Basingstoke.

Riggirozzi, P. 2010. "Social Policy in Post-Neo-Liberal Latin America: the Cases of Argentina, Venezuela and Bolivia." Development 53(1): 70-76.

Roberts, S. Marin, A., Moshes, A. and Pynnöniemi, K. 2014. The Eurasian Economic Union: Breaking the pattern of post-Soviet integration? FIIA Analysis - 3: The Finnish Institute of International Affairs.

Schimmelfennig, F. 2002 "Liberal Community and Enlargement: an Event History Analysis.” Journal of European Public Policy, 9 (4): 598-626.

Schimmelfennig, F. 2016. "Europe.” In The Oxford Handbook of Comparative Regionalism edited by Börzel, T. and Risse, T. Oxford: Oxford University Press.

Silitski, V. 2006. Contagion Deterred: Pre-emptive Authoritarianism in the Former Soviet Union (the Case of Belarus). Centre on Democracy, Development, and the Rule of Law, Working Paper, 2006.

Silitski, V. 2010. "Survival of the Fittest: Domestic and International Dimensions of the Authoritarian Reaction in the Former Soviet Union Following the Coloured Revolutions." Communist and Post-Communist Studies 43(4): 339-350.

Söderbaum, F. 2004. "Modes of Regional Governance in Africa: Neoliberalism, Sovereignty Boosting, and Shadow networks." Global Governance, 10(4): 419-436.

Söderbaum, F. 2010. "With a Little Help From My Friends: How Regional Organizations in Africa Sustain Clientelism, Corruption and Discrimination." University of Gothenburg, last accessed $22^{\text {nd }}$ January 2015: http://www.pol.gu.se/digitalAssets/1316/1316597_soderbaum.panel1.pdf 
Taylor, I. 2011. “The EU's Perceptions and Interests towards China's Rising Influence on Human Rights in Africa." In China and the European Union in Africa: Partners or Competitors? Edited by Men, J. and Barton, B. Farnham: Ashgate.

Toumi, H. 2013: Saudi Arabia Ratifies GCC Security Treaty. Gulf News last accessed 17th September 2015, http://gulfnews.com/news/gulf/saudi-arabia/saudi-arabia-ratifies-gccsecurity-treaty-1.1231982

The Economist. 2011. "The International Criminal Court Bares its Teeth.” The Economist, last accessed $14^{\text {th }}$ March 2015: http://www.economist.com/node/18682044

US State Department. 2001. “The Gambia - Jammeh's West Africa Policy.” Wikileaks, last accessed $4^{\text {th }}$ March 2015: https://wikileaks.org/cable/2001/05/01BANJUL327.html Wilkinson, T. 2017. "Venezuela in Showdown with OAS, U.S. Over Political Prisoners." Los Angeles Times, last accessed $8^{\text {th }}$ March 2017: http://www.latimes.com/politics/washington/lana-essential-washington-updates-venezuela-in-show-down-with-1490616319-htmlstory.html

Witt, A. 2013. "Convergence on Whose Terms? Reacting to Coups d'état in Guinea and Madagascar." African Security 6(3): 257-275.

Yabi, G.O. 2010. The Role of ECOWAS in Managing Political Crisis and Conflict: The Cases of Guinea and Guinea-Bissau. Nigeria: Friedrich-Ebert-Stiftung, Regional Office.

Yom, S. 2014. "Authoritarian Monarchies as an Epistemic Community: Diffusion, Repression and Survival During the Arab Spring." Taiwan Journal of Democracy 10(1): 43-62. 